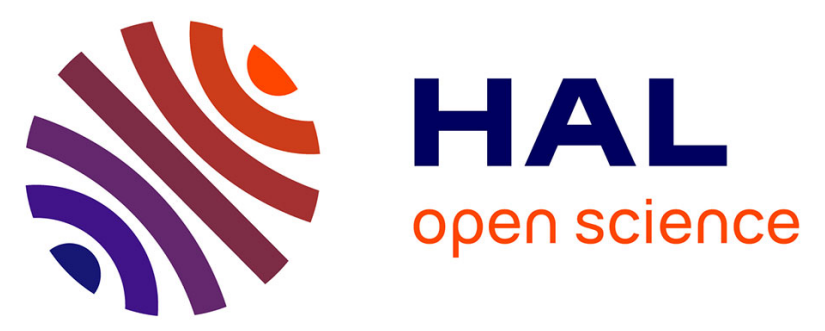

\title{
Do tubificid worms influence organic matter processing and fate of pollutants in stormwater sediments deposited at the surface of infiltration systems?
}

G. Nogaro, Florian Mermillod-Blondin, B. Montuelle, J.C. Boisson, M. Lafont, B. Volat, J. Gibert

\section{To cite this version:}

G. Nogaro, Florian Mermillod-Blondin, B. Montuelle, J.C. Boisson, M. Lafont, et al.. Do tubificid worms influence organic matter processing and fate of pollutants in stormwater sediments deposited at the surface of infiltration systems?. Chemosphere, 2007, 70 (2), p. 315 - p. 328. 10.1016/j.chemosphere.2007.06.002 . hal-00453858

\section{HAL Id: hal-00453858 https://hal.science/hal-00453858}

Submitted on 5 Feb 2010

HAL is a multi-disciplinary open access archive for the deposit and dissemination of scientific research documents, whether they are published or not. The documents may come from teaching and research institutions in France or abroad, or from public or private research centers.
L'archive ouverte pluridisciplinaire HAL, est destinée au dépôt et à la diffusion de documents scientifiques de niveau recherche, publiés ou non, émanant des établissements d'enseignement et de recherche français ou étrangers, des laboratoires publics ou privés. 
Author-produced version of the article published in Chemosphere 2007, 70 (2), 315-328.

The original publication is available at http://www.sciencedirect.com/ doi : 10.1016/j.chemosphere.2007.06.002 
1 Do tubificid worms influence organic matter processing and fate

2 of pollutants in stormwater sediments deposited at the surface of

\section{infiltration systems?}

5 Géraldine Nogaro ${ }^{\mathrm{a},{ }^{*}}$, Florian Mermillod-Blondin ${ }^{\mathrm{a}}$, Bernard Montuelle ${ }^{\mathrm{b}}$, Jean-

6 Claude Boisson $^{\mathrm{c}}$, Michel Lafont ${ }^{\mathrm{d}}$, Bernadette Volat $^{\mathrm{b}}$, Janine Gibert ${ }^{\mathrm{a}}$

${ }^{\text {a } U M R-C N R S ~ 5023, ~ L a b o r a t o i r e ~ d ' E c o l o g i e ~ d e s ~ H y d r o s y s t e ̀ m e s ~ F l u v i a u x, ~ U n i v e r s i t e ́ ~ C l a u d e ~}$ Bernard Lyon 1, 69622 Villeurbanne Cedex, France

${ }^{\mathrm{b}}$ CEMAGREF, Laboratoire d'Ecologie Microbienne des Hydrosystèmes Anthropisés, 3 bis Quai Chauveau, CP 220, 69336 Lyon Cedex 09, France

* Corresponding author. Tel.: +334 7243 2945; fax: +33 472431523. 


\section{Abstract}

20 The purpose of this study was to quantify the influences of tubificid worms on the

21 biogeochemical functioning of an infiltration system impacted by a stormwater sediment deposit. Effects of worms with stormwater sediment deposit were compared with effects of worms with two other natural sediment deposits (one low and one rich-particulate organic matter deposits). We measured the effects of invertebrates on sediment reworking, organic matter processing, solute fluxes, microbial characteristics, and pollutant release from stormwater deposit to water. Our results showed that tubificid worms had slight effects on microbial activities in presence of the stormwater deposit whereas they significantly stimulated microbial activities in columns impacted by the other two deposits. High contents of labile organic matter contained in stormwater sediments probably led to very strong microbial activities that could not be easily stimulated by worm activities. Moreover, tubificid 31 worms did not influence the fate of pollutants (heavy metals and PAHs) contained in the stormwater deposit. In conclusion, our study demonstrated that the organic matter characteristics of the stormwater sediments limited the efficiency of tubificid worms to stimulate organic matter mineralization in infiltration systems.

36 Keywords: Polluted sediments; Bioturbation; Microbial activities; Biogeochemical processes;

37 Slow infiltration columns 


\section{Introduction}

Management of urban stormwater consists in collecting and pouring stormwater into rivers, ponds or infiltration basins (Marsalek and Marsalek, 1997; Barraud et al., 2002). Such discharges of urban stormwater may cause numerous adverse effects including the import of heavy metals, organic compounds and pathogens to receiving waters (Pitt et al., 1999). Most pollutants transported by stormwater are associated with suspended sediments (Pitt et al., 1999), these sediments being retained into the beds of rivers and infiltration basins. For example, Datry et al. (2003b) estimated that a total of $4588 \mathrm{~kg}$ of particulate organic carbon, $284 \mathrm{~kg}$ of particulate nitrogen, $284 \mathrm{~kg}$ of particulate phosphorus, $128 \mathrm{~kg}$ of hydrocarbons, and $153 \mathrm{~kg}$ of heavy metals $(\mathrm{Zn}, \mathrm{Pb}, \mathrm{Cu}, \mathrm{Cr}, \mathrm{Ni}$, and $\mathrm{Cd})$ were retained in a small infiltration basin draining an urban catchment of 2.5 ha. Such characteristics of stormwater sediments may strongly affect biogeochemical processes occurring at the water-sediment interface (Datry et al., 2003a, b; Nogaro et al., in press).

Despite high pollutant contents, stormwater deposits may be colonised by invertebrate taxa adapted to life in suboxic and contamined environments such as tubificids worms (Datry et al., 2003a). In stormwater sediments, these worms can create dense networks of burrows and galleries (Mermillod-Blondin et al., 2005). Most bioturbation activities of worms could stimulate the solute exchanges (oxygen and metabolites) across the water-sediment interface and then the microbial processes such as nitrification and denitrification (Pelegri and Blackburn, 1995; Svensson et al., 2001). In stormwater deposits, Mermillod-Blondin et al. (2005) showed that tubificids could stimulate the organic matter mineralization and the release of nutrients and pollutants in stagnant systems. However, the influence of worms on the mineralization of stormwater deposits in infiltration systems (such as infiltration basins or hyporheic zone of rivers) has never been studied.

The aim of this study was to quantify the worm effects on mineralization rates of stormwater deposits (collected in urban area). These effects were compared with those 
measured in two natural sediment deposits characterized by different particulate organic matter (POM) contents in order to determine if the urban deposits specifically influenced worm effects in the infiltration system. With these aims, our experiment were done using infiltration columns filled with gravel and sand with inputs of sediment deposits with different characteristics (POM) in surface and supplied by water under a constant flow rate. We measured the effects of invertebrates on sediment reworking, organic matter processing $\left(\mathrm{O}_{2}\right.$ uptake), solute fluxes (fluxes of $\mathrm{NO}_{3}^{-}, \mathrm{NO}_{2}^{-}, \mathrm{NH}_{4}^{+}$, and $\mathrm{COD}$ ), microbial characteristics (biomass, functional diversity and activities), and pollutant release rates from stormwater deposits to water. Our first hypothesis was that the effects of tubificid worms in stormwater deposits would be significantly different than the effects measured in other deposits due to the physico-chemical characteristics of the three sediment deposits (quantity of POM, quality of POM-C/N and C/P ratios-, and occurrence of pollutants). We also hypothesized that tubificid worms could modify the fate of pollutants (hydrocarbons and heavy metals) in the system impacted by stormwater sediment deposits.

\section{Materials and methods}

\subsection{Sediment columns}

Experiments were carried out in slow infiltration columns (Mermillod-Blondin et al., 2000). Each column (height $=45 \mathrm{~cm}$ and inside diameter $=10 \mathrm{~cm}$ ) was constituted by association of four experimental modules $(10 \mathrm{~cm}$ high) topped by a fifth module $5 \mathrm{~cm}$ high. We used 18 columns which were filled with a mixture of gravel and sand in order to constitute a deep layer of heterogeneous sediment $(28 \mathrm{~cm}$ depth) with a $2 \mathrm{~cm}$ sediment layer in surface. Three different types of sediment deposit were added at the surface: (1) a stormwater (STORM) deposit, (2) a particulate organic matter-rich (POM-rich) deposit, and (3) a particulate organic matter-low (POM-low) deposit. 


\subsection{Preparation of heterogeneous sediments and sediment deposits}

\subsubsection{Heterogeneous sediment (gravel and sand)}

Gravel and sand were collected from the Rhône River. Gravel was sieved manually to select particle sizes ranging from 5 to $8 \mathrm{~mm}$ and then was cleaned with deionized water before being dried at $60^{\circ} \mathrm{C}$. Before filling the columns, $18 \mathrm{~kg}$ of dry sand were manually mixed with $90 \mathrm{~g}$ of fibrous cellulose powder $(0.5 \%$ of the sediment weight $)$ to stimulate the microbial growth. A volume of $10 \mathrm{~L}$ of synthetic water $\left(96 \mathrm{mg} \mathrm{L}^{-1} \mathrm{NaHCO}_{3}, 39.4 \mathrm{mg} \mathrm{L}^{-1} \mathrm{CaSO}_{4}, 2 \mathrm{H}_{2} \mathrm{O}\right.$, $60 \mathrm{mg} \mathrm{L} \mathrm{MgSO}_{4}, 7 \mathrm{H}_{2} \mathrm{O}, 4 \mathrm{mg} \mathrm{L}{ }^{-1} \mathrm{KCl}, 19 \mathrm{mg} \mathrm{L}^{-1} \mathrm{Ca}\left(\mathrm{NO}_{3}\right)_{2}, 4 \mathrm{H}_{2} \mathrm{O}$, and $1.6 \mathrm{mg} \mathrm{L}^{-1}$ $\left.\left(\mathrm{CH}_{3} \mathrm{CO}_{2}\right)_{2} \mathrm{CaH}_{2} \mathrm{O}\right)$ was added to the sand which was inoculated with an extract of natural bacteria as described by Mermillod-Blondin et al. (2000).

\subsubsection{Different types of fine sediment deposits}

The STORM deposit was collected on a stormwater infiltration basin located on the campus of the University Claude Bernard (Lyon, France). The POM-rich and the POM-low deposits were collected on braided channels of the Rhône River at about $80 \mathrm{~km}$ east of Lyon. These three types of fine sediment deposit were sieved $(<1000 \mu \mathrm{m})$ and homogenized in the laboratory before use. The particle size distributions of different fine deposits (STORM, POM-low, and POM-rich deposits) were determined by a laser diffraction granulometer (Mastersizer 2000, Malvern Instrument, UK). The STORM, the POM-rich, and the POM-low deposits were characterized by a high proportion of fine sediment particles with respectively $42-48,45-52$, and $47-54 \%$ of volume of particles lower than $100 \mu \mathrm{m}$.

\subsection{Experimental design}

Each column was filled with the sand previously incubated and gravels to a height of 28 cm on day -11 (11 days before fauna deposit). Constant masses of gravels $(600 \mathrm{~g})$ and incubated sand (215 g) were alternately added (five times) and finally $150 \mathrm{~g}$ of sand were 
116 added at the sediment surface in order to obtain a heterogeneous interface corresponding as

117 much as possible to river natural sediments. On day -9 , the columns were supplied with 118 synthetic water with a peristaltic pump controlling a constant infiltration flow rate of $1.5 \mathrm{ml}$ $\min ^{-1}$. On day $-6,100 \mathrm{~g}$ of incubated sand were added in each column before that of surface

120 deposit to prevent a too important penetration of the surface deposit in the heterogeneous 121 matrix. Then, we added $250 \mathrm{~g}$ of each sediment deposit (STORM, POM-low and POM-rich 122 deposits) in each deposit treatment (6 columns per deposit treatment). The total height of 123 sediment in each column was $30 \mathrm{~cm}(28 \mathrm{~cm}$ of heterogeneous sediment and $2 \mathrm{~cm}$ of fine deposit). The use of a $2 \mathrm{~cm}$ layer of fine deposit was in accordance with the thickness of fine sediments reported on the bed of infiltration basins (Bedell et al., 2004) and rivers (Wood and Armitage, 1997). About $10 \mathrm{~cm}$ of water was left above the sediment surface.

On day 0 , tubificids were introduced in the columns (in free water). For each surface deposit treatment (STORM, POM-rich, and POM-low deposits), two fauna treatments were performed with three replicates per treatment: (1) without invertebrate (controls) and (2) with 160 tubificid worms per experimental unit. The invertebrate densities used in our experiment

131 (20 400 individuals. $\mathrm{m}^{-2}$ ) were typical for lakes and streams (McCall and Fisher, 1980).

132 Tubificids were collected from the Rhône River and were about 60\% Tubifex $s p$. and 40\%

133 Limnodrilus sp. For acclimation to experimental conditions (particle size and temperature),

134 animals were kept in the laboratory for more than 10 days before use in infiltration columns.

135 At the end of the experiment, we recovered $68.8 \pm 21.7 \%$ (mean $\pm \mathrm{SD}, \mathrm{n}=9$ ) of the animals

136 added initially. Experiments were performed at constant temperature $\left(15 \pm 0.5^{\circ} \mathrm{C}\right)$ and the

137 light was controlled on a $12 \mathrm{~h}$ light, $12 \mathrm{~h}$ dark cycle in the overlying water. In contrast, the

138 sediment of the column was kept in the dark to suppress photoautotrophic growth. 
Concentrations of particulate organic matter (POM), particulate organic carbon (POC),

143 particulate nitrogen (PN), particulate phosphorus (PP), heavy metals, and polycyclic aromatic hydrocarbons (PAHs) were determined in the three sediment deposits (STORM, POM-rich, and POM-low deposits) and in the sand of the heterogeneous sediment. The measurements were performed in fresh material before use in experimental columns to characterize the chemical properties of the different deposits and the bed sediment layer.

POM content was determined as loss upon ignition at $550^{\circ} \mathrm{C}$ for $5 \mathrm{~h}$. $\mathrm{POC}, \mathrm{PN}, \mathrm{PP}$, and heavy metal analyses were performed by the Central Service of Analysis of the French National Centre for Scientific Research (CNRS) in Lyon (France) following standard methods (Buchanan, 1984; Hedges and Stern, 1984). PAH analyses were performed by the Health and Environmental Laboratory of Lyon using a HPLC with fluorescence detectors (Agilent 1100).

\subsubsection{Sediment reworking analyses}

Luminophores (natural sediment particles covered with a luminescent paint) were used to estimate sedimentary reworking by invertebrates in the columns. The day after introduction of the invertebrates, $1 \mathrm{~g}$ of yellow luminophores $(160-315 \mu \mathrm{m})$ was deposited at the sediment surface of each column. At the end of the experiment, the water layer was carefully pumped out and the sediment of each column was cut into slices. The top $3 \mathrm{~cm}$ were sliced at $0.5 \mathrm{~cm}$ thickness while the next $7 \mathrm{~cm}$ were sliced in $1 \mathrm{~cm}$ layers. Each slice was sieved to remove gravel (with a sieve of $2 \mathrm{~mm}$ ) and recover living organisms (with a sieve of $500 \mu \mathrm{m}$ ). Five $\mathrm{g}$ of sieved sediment were taken from each slice and dried at $40^{\circ} \mathrm{C}$ for $48 \mathrm{~h}$ before being mixed delicately to homogenize the sediment without breaking the luminophores. Luminophores were counted with a U.V. light microscope and expressed as number of luminophore per gram of dry sediment. Sediment transport at the interface due to the invertebrate activities was estimated by comparing the vertical profiles of luminophores in each treatment (i.e. control 
167 and tubificid). Vertical profiles of luminophores in the sediment were obtained from

168 percentages of luminophore found in each slice for each column.

\subsubsection{Physico-chemical analyses}

171 Physico-chemical analyses were performed in water samples of slow infiltration columns to

172 study the biogeochemical processes in sedimentary columns. We measured dissolved oxygen

$173\left(\mathrm{O}_{2}\right)$, nitrate, nitrite, ammonium, dissolved organic carbon (DOC) in water samples taken

174 from different depths $(+5 \mathrm{~cm}$ above and $-1,-5,-15$, and $-25 \mathrm{~cm}$ below the water-sediment

175 interface) of slow filtration columns and at days 0 (before the fauna introduction), 2 (=2 days

176 after the fauna introduction), 6, 10, 14, and 20. Measurements of nitrates, ammonium, and

177 DOC were also performed in the tank containing the supplied synthetic water and at $-25 \mathrm{~cm}$

178 below the water-sediment interface of each column every second day during the course of the

179 experiment (from days 1 to 20 ). The average release rate of each solute for each column and

180 then, the average release rate per fauna treatment (control vs. tubificid) for each deposit 181 treatment were calculated.

182 Dissolved $\mathrm{O}_{2}$ measurements were done according to the method of Mermillod-Blondin et

183 al. (2000) using a 3600 Orbisphere model oxygen meter. Nitrate, nitrite and ammonium 184 contents were measured using colorimetric HACH methods according to Mermillod-Blondin 185 et al. (2000). For DOC measurements, water samples were measured according to the method 186 of Mermillod-Blondin et al. (2000) using a Dohrman DC 80 “Total carbon analyser”.

\subsubsection{Microbial analyses}

189 Microbial analyses were performed in sediment at different depth to study the influence of 190 worms on microbial communities, activities and functional diversity in presence of different 191 sediment deposits. At the end of experiments (on day 22), the water layer was carefully

192 pumped and the sediment of each column was collected from four depth layers $(0-3,3-6,13-$ 
193 16, and 23-26 cm). Each layer was sieved to remove gravel (with a sieve of $2 \mathrm{~mm}$ ) and

194 recover living organisms (with a sieve of $500 \mu \mathrm{m}$ ).

195 The DNA intercalating dye (DAPI) and a Cy3-probe (EUB 338, eubacteria) were used on 196 sediment samples to determine the total numbers of bacteria stained with DAPI and the 197 percentages of active eubacteria (\% EUB/DAPI). Two g of wet sediment were taken in each 198 layer and were prepared according to Mermillod-Blondin et al. (2005). Numbers of DAPI and

199 Cy3-bacteria were counted separately from the same field in order to calculate the percentages 200 of active bacteria (EUB/DAPI) and the total numbers of bacteria stained with DAPI from each 201 analyzed field. Results were expressed as numbers of bacteria $\mathrm{g}^{-1}$ of sediment dry weight 202 (DW).

Activity (global Average Well Colour Development) and functional diversity (number of 204 substrates used) were measured with Biolog ECO microplates. Details concerning the 205 methods of analysis were given in Nogaro et al. (in press).

206 Aerobic respiration and denitrification were performed following the slurry technique 207 (Furutani et al., 1984). About $10 \mathrm{~g}$ of wet sieved sediment of each sediment layer were 208 prepared according to Nogaro et al. (in press). Results were expressed as $\mu \mathrm{g}$ of $\mathrm{C}_{\text {or }} \mathrm{N} \mathrm{h}^{-1} \mathrm{~g}^{-1}$ 209 sediment DW. Hydrolytic activity was measured using fluorescein diacetate (FDA) as 210 substrate for hydrolases (Fontvieille et al., 1992). Three wet sieved sediment samples (0.95$2111.05 \mathrm{~g}$ ) of each sediment layer were prepared following Nogaro et al. (in press). Results were 212 expressed as micromoles of hydrolyzed FDA h ${ }^{-1} \mathrm{~g}^{-1}$ of sediment DW.

\section{2.4.5. Hydrocarbon and heavy metal release from stormwater sediment deposit to water}

215 Concentrations of 4 heavy metals and 15 hydrocarbons widely found in stormwater 216 sediments (Datry et al., 2003b) were measured in water at the outlet of the columns on days 1, 2178 and 15 of the experiment in the columns with STORM deposit in surface (Table 2). 
Analyses of hydrocarbons and metals in water were performed by the Health and

219 Environmental Laboratory of Lyon following standard methods (Clesceri et al., 1998).

\subsection{Data treatment}

We tested the effects of fauna treatment (control and tubificid) and sediment deposit treatment (STORM, POM-low, and POM-rich deposits) on the percentage of luminophore found at each depth using a two-way analysis of variance (ANOVA). If significant differences were detected, Scheffé post hoc tests were performed to determine if the effect of tubificids were observed for each deposit treatment.

For physico-chemical variables $\left(\mathrm{O}_{2}, \mathrm{NO}_{3}{ }^{-}, \mathrm{NH}_{4}{ }^{+}\right.$and $\left.\mathrm{COD}\right)$, we tested the homogeneity among the columns on day 0 (before the fauna deposition) using a two-way ANOVA for each type of surface deposit with fauna treatment (i.e. control and tubificid) and depth $(+5 \mathrm{~cm}$ above and $-1,-5,-15,-25 \mathrm{~cm}$ below the water-sediment interface) as main effects. After fauna addition, a two-way repeated measures ANOVA (RM-ANOVA) was used on physicochemical variables to detect differences among fauna treatments and depths using time as repeated factor (days 2, 6, 10, 14, and 20). If significant differences were detected among

234 fauna treatments, Scheffé post hoc tests were performed to determine the differences among 235 fauna treatments for each depth and time. For the average release rates of solutes $\left(\mathrm{NH}_{4}{ }^{+}\right.$and DOC) from days 1 to 20 , we tested the effects of fauna treatment and surface deposit treatment using a two way ANOVA and Scheffé post hoc tests.

For bacterial measurements, we tested the fauna treatment and depth effects using a twoway ANOVA and Scheffé post hoc tests for each type of surface deposit. We tested the fauna 240 treatment and time (measurements performed at days 1,8 and 15) on metal and PAH release rates using two-way ANOVA with fauna treatment and time as main effects.

242 When necessary, data were log-transformed, and data expressed as percentages $(\%$ of 243 luminophore and active bacteria) were arcsine-transformed before statistical analysis, to fit 
244 the assumption of homoscedasticity. Statistical analyses were performed using Statistica 6 TM 245 (Statsoft, Tulsa, OK, USA).

\section{Results}

\subsection{Composition of the surface sediment deposits and the heterogeneous sediment}

The STORM and the POM-rich deposits had high POM and POC contents compared to the POM-low deposit (Table 1). The concentrations of PN and PP were higher in the STORM deposit than in the two other deposits. The STORM and the POM-low deposits had comparable atomic ratio of $\mathrm{C} / \mathrm{N}$ and $\mathrm{C} / \mathrm{P}$ which were higher than those of the POM-rich deposit. Moreover, STORM deposit was characterized by high concentrations of heavy metals and hydrocarbons whereas no pollutants were detected in the other sediment deposits.

Before use in experimental column, the sand of the heterogeneous sediment layer was characterized by $17.3 \pm 1.2,7.7 \pm 0.6,0.3 \pm 0.06$, and $0.16 \pm 0.01$ g.kg ${ }^{-1}$ sed. DW of POM, POC, PN, and PP, respectively (mean $\pm \mathrm{SD}, \mathrm{n}=3$ ). No pollutants (heavy metals and hydrocarbons) were detected in the sand in all experimental columns at the beginning and at the end of the experiment.

\subsection{Sediment reworking analyses}

In the control columns, more than $97 \%$ of the luminophores were in the upper layer $(0.5$ cm depth) of sediments at the end of the experiment (Fig. 1). In the animal treatments, the

264 percentages of luminophores in this upper layer were $60.5 \pm 11.1,84.7 \pm 4.9$, and $63.7 \pm 15.8$ $265 \%$ in presence of STORM, POM-low, and POM-rich deposits, respectively. These 266 percentages were significantly different among control and tubificid treatments depending on 267 the type of deposit (Fig. 1, two-way ANOVA, interaction "fauna x deposit" effect, $p<0.05$ ). 268 The tubificids significantly buried luminophores at depth (Scheffé post hoc tests, $p<0.001$ ) 269 and with a same intensity in presence of STORM and POM-rich deposits treatments (Scheffé 
270

271

272

273

274

post hoc test, $p>0.05$ ). In contrast, the percentages of luminophores measured at depth were not significantly different among control and tubificid treatments in the POM-low deposit treatment (Scheffé post hoc test, $p>0.05$ ).

\subsection{Physico-chemical analyses}

On day 0 (before the fauna addition), no differences in concentrations of dissolved $\mathrm{O}_{2}$, $\mathrm{NO}_{3}{ }^{-}, \mathrm{NO}_{2}{ }^{-}, \mathrm{NH}_{4}^{+}$, and DOC were measured between the groups of columns assigned to each treatment (control vs. tubificid) whatever the type of surface deposit (two-way ANOVAs, fauna effect, $p>0.05$ ). During the experiment, oxygen and nitrate concentrations decreased significantly with depth in all columns (two-way RM-ANOVAs, depth effect, $p<0.05$, see Fig. 2 for day 14). After animal addition, occurrence of worms significantly reduced $\mathrm{O}_{2}$ concentrations with all sediment deposits (two-way RM-ANOVAs, fauna effect, $p<0.001$ ). This reduction of $\mathrm{O}_{2}$ concentrations by worms was however slight with the STORM deposit because Scheffé post hoc tests did not detect any effect of worms for each depth with STORM deposit ( $p>0.05$, see Fig. 2a for day 14). In contrast, the influence of worms on $\mathrm{O}_{2}$ concentrations was higher in the two other deposit treatments (POM-rich and POM-low deposits) where occurrence of worms led to significant reduction of $\mathrm{O}_{2}$ concentrations in interstitial water for different depths (Scheffé post hoc tests, $p<0.05$, see Figs. $2 b$ and $2 \mathrm{c}$ for day 14).

$\mathrm{NO}_{3}^{-}$concentrations were not significantly affected by tubificid worms during the experiment for the three sediment deposits (two-way RM-ANOVAs, fauna effect, $p>0.05$, see Fig. 2 for day 14).

Nitrite concentrations were very low $\left(<0.2 \mathrm{mg} \mathrm{L}^{-1}\right)$ in all columns throughout the experiment and no significant differences were detected between control and tubificid treatments in all deposit treatments (two-way RM-ANOVAs, fauna effect, $p>0.05$ ). 
During the experiment, $\mathrm{NH}_{4}{ }^{+}$and DOC concentrations significantly increased with depth 296 in the STORM and the POM-rich deposit treatments (two-way RM-ANOVAs, depth effect, $297 p<0.001)$. In the STORM deposit treatment, tubificid worms significantly increased the concentrations of $\mathrm{NH}_{4}{ }^{+}$in interstitial water (two-way RM-ANOVA, fauna effect, $p<0.001$ ) despite no significant influence on concentrations for each depth (Scheffé post hoc tests, $p>0.05$, see Fig. 2a for day 14). Such increased production of $\mathrm{NH}_{4}^{+}$due to worms was also 301 measured in the POM-rich deposit columns (two-way RM-ANOVA, fauna effect, $p<0.001$ ) with significant effects of worms observed at different depths (Scheffé post hoc tests, $p<0.05$, see Fig. $2 b$ for day 14). In presence of POM-low deposit, ammonium concentrations remained lower than $0.3 \mathrm{mg} \mathrm{L}^{-1}$ during the experiment with no significant difference between the fauna treatments (two-way RM-ANOVA, animal effect, $p>0.05$, see Fig. 2c for day 14). Tubificid worms did not significantly influence DOC concentrations in the STORM deposit treatment, (two-way RM-ANOVA, fauna effect, $p>0.05$ ). In contrast, tubificid worms increased the DOC concentrations in interstitial water with the two other deposits (two-way RM-ANOVAs, 309 fauna effect, $p<0.05$ ), this increase being the highest with the POM-rich deposit (see data of 310 day 14 on Fig. 2b).

311 The average release rates of $\mathrm{NH}_{4}{ }^{+}$and DOC measured from day 1 to day 20 (Table 2) were 312 significantly different among fauna treatments (control vs. tubificid) and surface deposit treatments (two-way ANOVAs, fauna effect and deposit effect, $p<0.05$ ). The mean releases

314 of ammonium and DOC were not significantly different between the control and the tubificid 315 treatments in presence of STORM and POM-low deposits (Scheffé post hoc tests, $p>0.05$ ). In 316 contrast, in presence of POM-rich deposit, tubificid worms increased by 40 and $30 \%$ the 317 release rates of $\mathrm{NH}_{4}{ }^{+}$and DOC, respectively (Scheffé post hoc tests, $p<0.05$ ).

\subsection{Microbial analyses}

At the end of the experiment, the total numbers of bacteria (stained with DAPI) decreased 321 significantly with depth with no significant difference among the fauna treatments for the 3 
deposits (Fig. 3, two-way ANOVAs, fauna effect, $p>0.05$, depth effect, $p<0.001$ ). The

323 percentages of active bacteria (\% EUB/DAPI) also decreased significantly with depth for all deposit treatments (Fig. 3, two-way ANOVAs, depth effect, $p<0.001$ ). The percentages of active bacteria were not significantly different among fauna treatments (control vs. tubificid) in the STORM deposit treatment (Scheffé post-hoc tests, $p>0.05$ ). In contrast, in presence of POM-low deposits, the percentages of active bacteria were increased by more than $30 \%$ in tubificid treatment in the first two layers of sediment $(0-3$ and $3-6 \mathrm{~cm})$ compared to the controls (Scheffé post-hoc tests, $p<0.01$ ). In the POM-rich deposit columns, these percentages of active bacteria were also higher in presence of fauna for the first three sediment layers $(0-$ 3, 3-6 and 13-16 cm; Scheffé post-hoc tests, $p<0.05)$.

The microbial activities measured with biolog (global AWCD) at the end of the experiment varied significantly with depth for the 3 sediment deposits but no significant differences were detected among control and tubificid treatments (Fig. 3, two-way ANOVAs, depth effect, $p<0.001$; fauna effect, $p>0.05$ ). The functional diversity measured with Biolog (numbers of substrates used), varied also significantly with depth for the 3 sediment deposits (Fig. 3, two-way ANOVAs, depth effect, $p<0.05$ ). Moreover, significant differences among control and tubificid treatments were only detected in the STORM deposit treatment (twoway ANOVA, fauna effect, $p<0.05$ ) where the functional diversities in the two first sediment layers $(0-3$ and 3-6 cm) were increased by more than $40 \%$ in tubificid treatment compared to the controls (Scheffé post-hoc tests, $p<0.05$ ).

At the end of the experiment, respiratory, denitrification, and hydrolytic activities in presence of the STORM deposit decreased significantly with depth with no significant difference among fauna treatments (Fig. 4, two-way ANOVAs, fauna effect, $p>0.05$, depth effect, $p<0.001)$. In the POM-low deposit treatment, respiration, denitrification and hydrolytic activities were very low in all sediment layers (i.e. for hydrolytic activity: $<0.02 \mu$ mol. $\mathrm{h}^{-1} \cdot \mathrm{g}^{-1}$ sed. DW) and did not show significant differences among fauna treatments and depths (Fig. 4, 
two-way ANOVAs, fauna effect, $p>0.05$, depth effect, $p>0.05$ ). In contrast, respiration and

349 denitrification potentials decreased significantly with depth in the POM-rich deposit treatment 350 (Fig. 4, two-way ANOVAs, depth effect, $p<0.001$ ). No significant effect of fauna was 351 detected in the POM-rich deposit treatment for the respiration potential (two-way ANOVA, 352 fauna effect, $p>0.05$ ), whereas denitrification and hydrolytic activities were increased by $94 \%$ 353 and $100 \%$ respectively in the first sediment layer by the presence of tubificid worms (two354 way ANOVAs, fauna effect, $p<0.001$, Scheffé post-hoc tests, $p<0.01$ ).

\subsection{Hydrocarbon and heavy metal release from stormwater deposit to water}

Only 3 PAHs (acenaphthene, naphtalene and phenanthrene) and one heavy metal (lead) were detected in water at the outlet of all the columns with STORM deposit in surface during all the experiment (Table 3). Concerning the releases of these pollutants (naphtalene, acenaphthene, phenanthrene and lead) from STORM deposit to water, no significant differences were detected between control and fauna treatments during the experiment (twoway ANOVAs, fauna effect, $p>0.05)$.

\section{Discussion}

\subsection{Effects of worms}

Our results showed that several processes $\left(\mathrm{O}_{2}\right.$ uptake, DOC and $\mathrm{NH}_{4}^{+}$productions, 367 hydrolytic activity ...) could be stimulated by worm activities in sediments. For instance, all 368 the columns showed a sharp decrease of oxygen and nitrate with depth (due to aerobic 369 microbial degradation of OM and denitrification) and, this oxygen decrease was enhanced by 370 the presence of worms. The direct effects of tubificid worms on $\mathrm{O}_{2}$ uptake (own respiration of 371 worms, McCall and Fisher, 1980; Mermillod-Blondin et al., 2005) could explain less than $3720.03 \mathrm{mg} \mathrm{L}^{-1}$ of differences in oxygen concentrations measured between control and fauna 373 columns. Because reduction of $\mathrm{O}_{2}$ concentration due to worms were higher than $0.3 \mathrm{mg} \mathrm{L}^{-1}$ in 
the 5 top cm of sediments with POM-rich and POM-low deposits (Fig. 2), the influence of

375 worms was predominantly due to a stimulation of microbial activity in these two deposits (as demonstrated by the percentage of active eubacteria in POM-low and POM-rich deposit treatments). According to several studies (e.g. Chatarpaul et al., 1980; Mermillod-Blondin et al., 2000; Svensson et al., 2001), the worm effects on biogeochemical processes were due to their particular mode of feeding and reworking activities. Burrowing, construction of galleries, feeding and production of faecal pellets by tubificid worms increased the exchanges of solutes and particles across the water-sediment interface, enhanced the accessibility of $\mathrm{O}_{2}$ and nutrients to anaerobic environments, and, as a consequence, induced a stimulation of microbial rates and pathways (Mermillod-Blondin et al., 2000; Svensson et al., 2001). During the experiment, faecal pellets were observed at the sediment surface of tubificid columns for all surface deposit treatments. Such pelletized layer at the sediment surface could be a favourable area for the development of microbes and could act as a high biogeochemical reactive zone. Moreover, the grazing of fine particles and attached bacteria by worms could stimulate the bacterial growth rates as shown with nematodes by Traunspurger et al (1997). All these feeding and reworking activities probably stimulated the aerobic and anaerobic bacterial communities and the microbial growth in sediment columns. However, the tubificid worms did not affect similarly microbial processes in the three sediment deposits. According to our hypothesis, the effects of worms depended on the physico-chemical characteristics of the sediments (POM quantity and quality- $\mathrm{C} / \mathrm{N}$ and $\mathrm{C} / \mathrm{P}$ ratios-).

\subsection{Interactions between tubificid effects and physico-chemical characteristics of the} stormwater deposit

\subsubsection{Tubificid effects in STORM and POM-low deposits = influence of the POM quantity}

The quantity of POM measured in the STORM deposit was more than 3-fold higher than those measured in the POM-low deposit whereas the qualities of POM (expressed as $\mathrm{C} / \mathrm{N}$ and 
$\mathrm{C} / \mathrm{P}$ ratios) measured in these two deposits were similar. This difference in POM quantity

401 could explain the lower microbial metabolism measured in the POM-low deposit treatment 402 than those measured in the STORM deposit treatment (as detailed in Nogaro et al., in press). 403 For instance, in control columns higher mean releases of ammonium $(\times 3.8)$ and DOC $(\times 4.3)$ 404 at depth were measured in presence of the STORM deposit than with the POM-low deposit. 405 The bacterial biomass (numbers of total bacteria) and activities (global AWCD, respiration, 406 denitrification and hydrolytic activities) were also relatively low in the POM-low deposit 407 treatment in comparison with the STORM deposit (Nogaro et al., in press). Less substrate 408 could lead to a lower stimulation of the microbial metabolism and / or a lower activity of 409 invertebrates in the sediment (in particular the feeding activity, Gremare et al., 2004). The 410 depth profiles of luminophores were in accordance with this assumption because a lower 411 bioturbation activity of worms was measured in the POM-low deposit treatment in 412 comparison with the STORM deposit treatment (with a high POM content). However, if 413 worms had a lower sediment reworking activity in the POM-low deposit treatment, the worm 414 effects on oxygen uptake and number of active eubacteria were more effective in presence of 415 POM-low deposit than with STORM deposits. Kristensen et al. (1992) stated that the 416 influence of benthic organisms in POM mineralization was positively related to the quantity 417 of the POM. In our system, the higher quantity of organic particles in the STORM deposit 418 probably led to an increase of the feeding and the burrowing activities of worms but also to 419 lower effects of fauna on sediment metabolism than in presence of a sediment with a lower 420 OM content. The high rates of POM mineralization measured in control columns with 421 STORM deposit probably limited the ability of worms to increase this mineralization rates. 422 For instance, oxygen concentrations measured on day 10 decreased sharply from the surface $423\left(7.3 \pm 0.1 \mathrm{mg} \mathrm{L}^{-1}\right)$ to $5 \mathrm{~cm}$ depth $\left(1.1 \pm 0.05 \mathrm{mg} \mathrm{L}^{-1}\right)$ in control columns with STORM deposit 424 whereas this decrease was less marked in controls with POM-low deposit (from $7.7 \pm 0.1 \mathrm{mg}$ $425 \mathrm{~L}^{-1}$ at the surface to $3.4 \pm 0.3 \mathrm{mg} \mathrm{L}^{-1}$ at $5 \mathrm{~cm}$ depth). In these conditions, the aerobic microbial 
activity $\left(\mathrm{O}_{2}\right.$ consumption $)$ in STORM deposit could not be easily stimulated by worms

whereas a stimulation of $\mathrm{O}_{2}$ consumption could occur in the POM-low deposit treatment because the respiration process was less saturated. Therefore, the relationship between worm activities in the sediment and their effects on microbial metabolism depends strongly on the POM resources of the sedimentary habitat.

\subsubsection{Tubificid effects on STORM and POM-rich deposits = influence of the POM quality}

Despite similar bioturbation activities in the STORM and the POM-rich deposits, the worms did not affect similarly the biogeochemical processes in these two types of sediment deposits characterized by high and comparable contents of POM. This difference may be linked to differences in quality of POM between STORM and the POM-rich deposits: the STORM deposit was characterized by a higher quality (lability) of its POM (indicated by lower $\mathrm{C} / \mathrm{N}$ and $\mathrm{C} / \mathrm{P}$ ratios) than the POM-rich deposit (Table 1).

In the POM-rich deposit, several processes $\left(\mathrm{O}_{2}\right.$ uptake, DOC and $\mathrm{NH}_{4}^{+}$productions, hydrolytic activity ...) were stimulated by worms whereas such stimulations did not occur in the STORM deposit at the exception of the functional diversity of micro-organisms measured with Biolog. This increase of the functional diversity of microbial communities (Fig. 3) by more than $40 \%$ in the two first sediment layers of the STORM deposit treatment was due to an increase of the diversity of carbon substrates due to worm activities. This specific effect of tubificid worms could be due to the chemical composition of the STORM sediment and, in particular, its high ability to produce a high diversity of carbon substrates. However, despite this worm effect on the microbial diversity, worms did not influence the microbial activities in presence of the STORM deposit. The higher effects of worms in the POM-rich treatment in comparison with the STORM deposit treatment may be linked to the differences in microbial activities measured without fauna in the two deposits. For instance, in control columns denitrification and hydrolytic activities were respectively 2.7-, and 3.9-fold higher in the first 
452 sediment layer $(0-3 \mathrm{~cm})$ in the STORM deposit treatment compared to the same layer in the 453 POM-rich deposit treatment. It was probable that the worms did not influence the 454 biogeochemical processes and microbial metabolism in STORM deposit treatment because of 455 the high mineralization rates occurring in the stormwater deposit. As discussed in the section 456 4.2.1., the microbial metabolism was probably saturated by the high content of labile POM in 457 the STORM deposit reducing the ability of worms to stimulate biogeochemical processes. In 458 marine sediments, several studies (Andersen and Kristensen, 1992; Kristensen et al., 1992; 459 Hansen and Kristensen, 1998) showed that the benthic organisms had a greater influence on 460 the mineralization of refractory POM than on that of the labile POM in marine sediments. 461 According to these studies, we also observed a higher effect of worms on mineralization in 462 the POM-rich deposit characterized by a relatively old and refractory POM (with the highest $463 \mathrm{C} / \mathrm{N}$ ) in comparison with the effects measured in the STORM deposit. Therefore, our results 464 highlight that the role of the fauna in sediments depends on the lability of the POM. More precisely, the organisms which reworked the refractory POM could increase its availability to an aerobic and anaerobic decomposition by micro-organisms whereas organisms could not increase strongly the availability of labile POM to micro-organisms.

\subsection{Interactions between tubificid worms and pollutant content in stormwater deposits}

Our second hypothesis of an effect of tubificid worms on the fate of pollutants (hydrocarbons and heavy metals) in the STORM deposit treatment was not validated. We expected that worm activities in the sediment (in particular the reworking and feeding activities of sediment particles) would lead to a stimulation of the pollutant release from the stormwater deposit to water. Invertebrate bioturbation was commonly recognized to have a significant effect on pollutant transports in the sediment (Caradec et al., 2004). It has also

476 been shown that the particular mode of feeding of tubificid worms (conveyor-belt species) 477 could influence the pollutant release (hydrocarbons) from sediment to water by increasing the 
resuspension of particles and the exchanges between sediment and water (Reible et al., 1996).

479 In our study, only some of the most soluble PAHs (naphthalene, acenaphthene and 480 phenanthrene) and one heavy metal (lead) were detected in water at the outlet of the columns 481 during the experiment. The concentrations of pollutants released in water were relatively low

482 ( $<90$ ng. $\mathrm{L}^{-1}$ for PAHs and $<25 \mu \mathrm{g} . \mathrm{L}^{-1}$ for the lead) and were not enhanced in presence of 483 tubificid worms. Such results were in accordance with Mermillod-Blondin et al. (2005) who 484 did not detect any effect of fauna on pollutant release from stormwater deposit to the 485 overlying water of stagnant systems. As shown by Datry et al. (2003b) in the field, the 486 stormwater deposits present in infiltration basins act as a sink for hydrocarbons and heavy 487 metals. It has also been demonstrated in marine sediments that the physico-chemical 488 characteristics (hydrophobicity and particle reactivity) of sediments could control the 489 influence of animal bioturbation on pollutant dynamic (Banta and Andersen, 2003). Our experiments therefore highlighted that the characteristics of the stormwater deposit lead to a high immobilisation of the pollutants in the system. From a management point of view, it is however necessary to analyse the long-term chemical interactions between sediment matrix and pollutants in order to quantify the water contamination potential due to accumulation of 494 pollutants in infiltration systems.

\section{Conclusion}

\section{Are activities of tubificid worms useful in management of stormwater sediments?}

Our study showed that the influence of invertebrates on biogeochemical processes and 499 microbial communities was greatly affected by the characteristics of the surface deposit 500 (quantity and quality of the POM) which control the activities of micro-organisms and 501 invertebrates in aquatic ecosystems. The high lability of POM of the STORM deposit induced 502 a high microbial activity which can not be easily stimulated by worms in infiltration conditions. 
In comparison with these infiltration conditions, Mermillod-Blondin et al. (2005) showed that tubificid worms increased the $\mathrm{O}_{2}$ uptake $(+35 \%)$ and the releases of $\mathrm{NH}_{4}{ }^{+}$and $\mathrm{DOC}$ by 2and 3-fold respectively, in stormwater deposits under stagnant conditions. These effects were due to the stimulation of microbial communities by enhancing the solute exchanges at the water-sediment interface. In our infiltration columns, the physically-induced flow rates within sediments probably played a significant role in the high metabolism of the STORM deposit treatment. For instance, Mermillod-Blondin et al. (2005) measured values of hydrolytic activity in the upper sediment layers (0-1 and 1-3 cm) of control columns (without fauna) were between 0.1 and $0.15 \mu \mathrm{mol} \mathrm{h}^{-1} \mathrm{~g}^{-1}$ sed. DW whereas our values in infiltration conditions were 2-fold higher in the first sediment layer $(0-3 \mathrm{~cm})$ of control columns. Oxygen and 514 metabolites $\left(\mathrm{NO}_{3}^{-}\right)$which were supplied at constant flow rate in the sediment columns during 515 all the experiment enhanced probably the sediment metabolism in comparison with stagnant conditions. Under infiltration conditions, bioturbation (bioirrigation) only modulates slightly the supply of $\mathrm{O}_{2}$ and nutriments for bacteria in infiltration systems whereas the same organism activity can produce fluxes of solutes at the water-sediment interface of stagnant systems and then can strongly influence microbial activities in sediments (Gerino et al., 2003; Mermillod-Blondin and Rosenberg, in press).

Therefore, our experiments suggest that efficiency of tubificid worms to stimulate organic matter processing in stormwater sediments would be optimized in stagnant systems such as retention ponds rather than in infiltration systems. Our conclusions should be however extended to other stormwater sediments. Considering the links between chemical characteristics of the stormwater deposit (complex composition with high contents of POM and contaminants) and the potentiality of tubificid worms to stimulate organic matter mineralization, testing the effect of tubificid worms in a set of stormwater deposits originating

528 from different drainage area (urban, industrial, agricultural zones) is greatly needed to make 529 generalizations. 


\section{Acknowledgments}

This work was a part of the OTHU project (Experimental Observatory for Urban 532 Hydrology) and was funded by the urban community of Lyon (COURLY) and the Rhône533 Alpes region. This study was also supported by the subvention $n^{\circ} 05 \mathrm{DST} 6006$ from the 534 DRAST (Direction de la Recherche de l'Animation Scientifique et Technique, Ministère 535 français des Transports, de l'Equipement, du Tourisme et de la Mer) and the Institut National 536 des Sciences de 1'Univers (n03N51/0532, Programme ECCO-PNBC). We thank G. Bouger, 537 M. Neto, A. Ohannessian and N. Garé for their help during sediment and water sampling.

\section{References}

540 Andersen, F.O., Kristensen, E., 1992. The importance of benthic macrofauna in 541 decomposition of microalgae in a coastal marine sediment. Limnol. Oceanogr. 37, 1392$542 \quad 1403$.

543 Banta, G.T., Andersen, O., 2003. Bioturbation and the fate sediment pollutants. Experimental 544 case studies of selected infauna species. Vie Milieu 53, 233-248.

545 Barraud, S., Gibert, J., Winiarski, T., Krajewski, J.L.B., 2002. Implementation of a 546 monitoring system to measure impact of stormwater runoff infiltration. Water Sci. Technol. $547 \quad 45,203-210$.

548 Bedell, J.P., Neto, M., Delolme, C., Ghidini, M., Winiarski, T., Perrodin, Y., 2004. Study of 549 physico-chemical and microbiological parameters of a soil in restored stormwater 550 infiltration basin in the Lyon area. In: Proceedings of Fifth International Conference 551 NOVATECH. June 2004, Lyon, pp. 1469-1476.

552 Buchanan, J.B., 1984. Sediment analysis. In: Holme, N.A., McIntyre, A.D. (Eds.). Methods 553 for the study of marine benthos. Blackwell Scientific Publications, Oxford, pp. 41-64. 
554 Caradec, S., Grossi, V., Hulth, S., Stora, G., Gilbert, F., 2004. Macrofaunal reworking 555 activities and hydrocarbon redistribution in an experimental sediment system. J. Sea Res. $556 \quad 52,199-210$.

557 Chatarpaul, L., Robinson, J.B., Kaushik, N.K., 1980. Effects of tubificid worms on 558 denitrification and nitrification in stream sediment. Can. J. Fish. Aquat. Sci. 37, 656 - 663.

559 Clesceri, L.S., Greenberg, A.E., Eaton, A.D., 1998. Standard methods for the examination of 560 water and wastewater. American Public Health Association, Washington.

561 Datry, T., Hervant, F., Malard, F., Vitry, L., Gibert, J., 2003a. Dynamics and adaptive 562 responses of invertebrates to suboxia in contaminated sediments of a stormwater infiltration 563 basin. Arch. Hydrobiol. 156, 339-359.

564 Datry, T., Malard, F., Hervant, F., Vitry, L., Gibert, J., 2003b. Solutes dynamics in the bed of a rapid infiltration storm water basin. J. Hydrol. 273, 217-233.

566 Fontvieille, D., Outaguerouine, A., Thevenot, D.R., 1992. Fluoresceine diacetate hydrolysis as a measure of microbial activity in aquatic systems. Application to activated sludge.

568 Environ. Technol. 13, 531-540.

569 Furutani, A., Rudd, J.W., Kelly, C.A., 1984. A method for measuring the response of 570 sediment microbial communities to environmental perturbations. Can. J. Microbiol. 30, 571 1408-1414.

572 Gerino, M., Stora, G., François-Carcaillet, F., Gilbert, F., Poggiale, J.-C., Mermillod-Blondin, 573 F., Desrosiers, G., Vervier, P., 2003. Macro- invertebrate functional groups in freshwater 574 and marine sediments: A common mechanistic classification. Vie Milieu 53, 221-232.

575 Gremare, A., Duchêne, J.C., Rosenberg, R., David, E., Desmalades, M., 2004. Feeding 576 behaviour and functional response of Abra ovata and A. nitida compared by image analysis. 577 Mar. Ecol. Prog. Ser. 267, 195-208.

578 Hansen, K., Kristensen, E., 1998. The impact of the polychaete Nereis diversicolor and 579 enrichment with macroalgal (Chaetomorpha linum) detritus on benthic metabolism and 
nutrient dynamics in organic-poor and organic-rich sediment. J. Exp. Mar. Biol. Ecol. 231, $581 \quad 201-223$.

582 Hedges, J.I., Stern, J.H., 1984. Carbon and nitrogen determinations of carbonate-containing 583 solids. Limnol. Oceanogr. 29, 657-663.

584 Kristensen, E., Andersen, F.O., Blackburn, T.H., 1992. Effects of benthic macrofauna and 585 temperature on degradation of macroalgal detritus: the fate of organic carbon. Limnol. $586 \quad$ Oceanogr. 37, 1404-1419.

587 Marsalek, J., Marsalek, P.M., 1997. Characteristics of sediments from a stormwater 588 management pond. Water Sci. Technol. 36, 117-122.

589 McCall, P.L., Fisher, J.B., 1980. Effects of tubificid oligochaetes on physical and chemical 590 properties of lake Erie sediments. In: Brinkhurst, R.O. and Cook, D.G. (Eds.). Aquatic 591 oligochaete biology. Plenum Press, New-York, pp. 253-317.

592 Mermillod-Blondin, F., Creuze des Chatelliers, M., Gerino, M., Gaudet, J.-P., 2000. Testing 593 the effect of Limnodrilus sp. (Oligochaeta, Tubificidae) on organic matter and nutrient 594 processing in the hyporheic zone: A microcosm method. Arch. Hydrobiol. 149, 467-487.

595 Mermillod-Blondin, F., Nogaro, G., Datry, T., Malard, F., Gibert, J., 2005. Do tubificid 596 worms influence the fate of organic matter and pollutants in stormwater sediments? 597 Environ. Pollut. 134, 57-69.

598 Mermillod-Blondin, F., Rosenberg, R. Ecosystem engineering: the impact of bioturbation on 599 biogeochemical processes in marine and freshwater benthic habitats (in press).

600 Nogaro, G., Mermillod-Blondin, F., Montuelle, B., Boisson, J.-C., Bedell, J.P., Ohannessian, 601 A., Volat, B., Gibert, J., Influence of a stormwater sediment deposit on microbial and 602 biogeochemical processes in infiltration porous media (in press).

603 Pelegri, S.P., Blackburn, T.H., 1995. Effects of Tubifex tubifex (Oligochaeta : Tubificidae) on $604 \mathrm{~N}$-mineralisation in freshwater sediments measured with $15 \mathrm{~N}$ isotopes. Aquat. Microb. $605 \quad$ Ecol. 9, 289-294. 
Pitt, R., Clark, S., Field, R., 1999. Groundwater contamination potential from stormwater 607 infiltration practices. Urban Water 1, 217-236.

608 Reible, D.D., Popov, V., Valsaraj, K.T., Thibodeaux, L.J., Lin, F., Dikshit, M., Todaro, M.A., 609 Fleeger, J.W., 1996. Contaminant fluxes from sediment due to tubificid oligochaete 610 bioturbation. Water Res. 30, 704-714.

611 Svensson J.M., Enrich-Prast A., Leonardson L., 2001. Nitrification and denitrification in a 612 eutrophic lake sediment bioturbated by oligochaetes. Aquat. Microb. Ecol. 23, 177-186.

613 Traunspurger, W., Bergtold, M., Goedkoop, W., 1997. The effects of nematodes on bacterial 614 activity and abundance in a freshwater sediment. Oecologia 112, 118-122.

615 Wood, P.J., Armitage, P.D., 1997. Biological effects of fine sediment in the lotic 616 environment. Environ. Manage. 21, 203-217.

617

\section{Figure Captions}

619 Fig. 1. Depth profiles of luminophore for (a) the STORM, (b) the POM-rich, and (c) the 620 POM-low deposits at the end of the experiment (mean $\pm \mathrm{SD}, \mathrm{n}=3$ ). Asterisks (*) indicate a significant difference between control and tubificid columns.

Fig. 2. Depth profiles of $\mathrm{O}_{2}, \mathrm{~N}_{-} \mathrm{NO}_{3}{ }^{-}, \mathrm{N}-\mathrm{NH}_{4}{ }^{+}$, and DOC concentrations on day 14 for (a) the STORM, (b) the POM-rich, and (c) the POM-low deposits (mean $\pm \mathrm{SD}, \mathrm{n}=3$ ). Asterisks $(*)$ indicate a significant difference between control and tubificid columns.

626

Fig. 3. Depth profiles of total numbers of bacteria (DAPI), \% of active bacteria (\% 628 EUB/DAPI), activity measured with biolog (global AWCD), and functional diversity 629 measured with Biolog (number of substrates) for (a) the STORM, (b) the POM-rich, and (c) 630 the POM-low deposits at the end of the experiment (mean $\pm \mathrm{SD}, \mathrm{n}=3$ ). Asterisks (*) indicate 631 a significant difference between control and tubificid columns. 
632 Fig. 4. Depth profiles of respiratory, denitrification, and hydrolytic activities for (a) the 633 STORM, (b) the POM-rich, and (c) the POM-low deposits at the end of the experiment (mean $634 \pm \mathrm{SD}, \mathrm{n}=3$ ). Asterisks $(*)$ indicate a significant difference between control and tubificid 635 columns. 
(a) STORM deposit

Luminophore (\%)

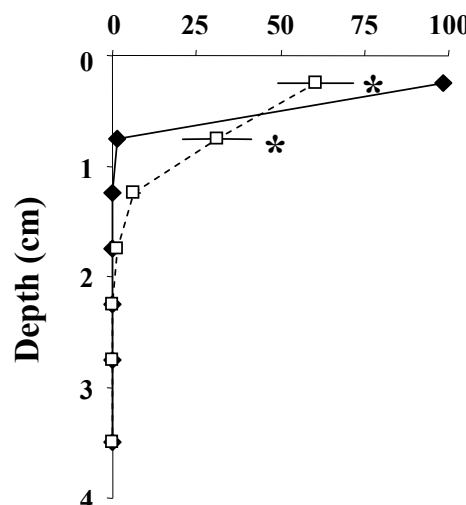

4 (b) POM-rich deposit

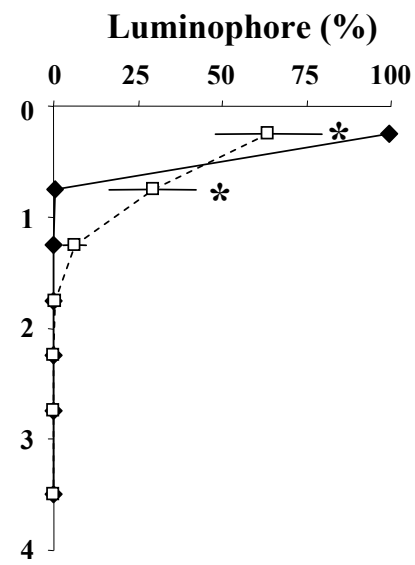

(c) POM-low deposit

Luminophore (\%)

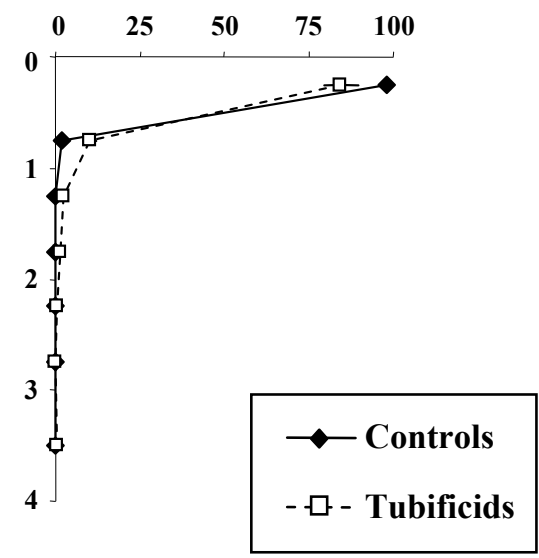

Fig. 1. 


\section{(a) STORM deposit}
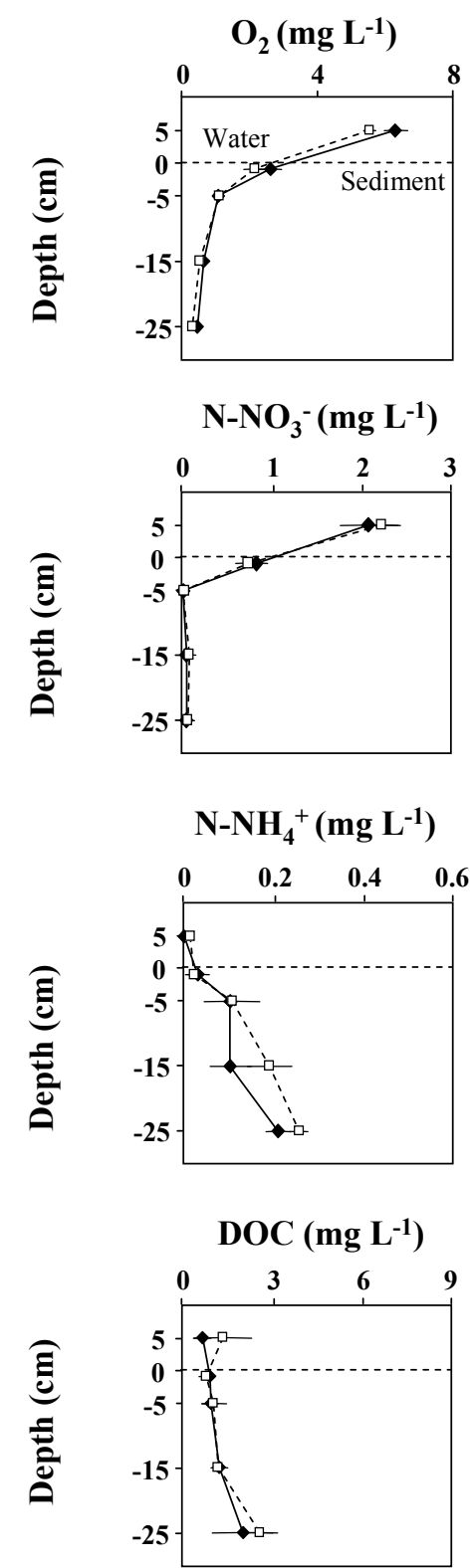

(b) POM-rich deposit
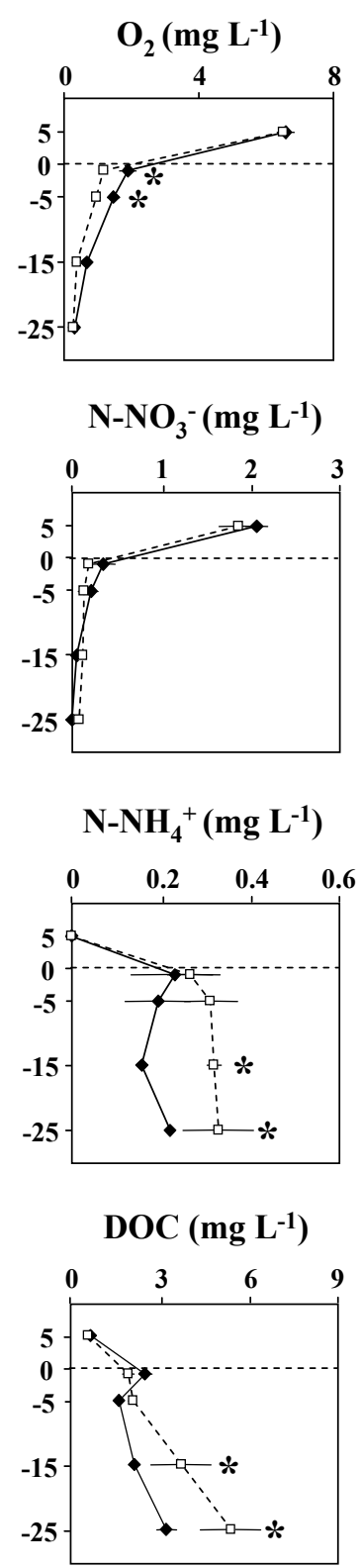

(c) POM-low deposit
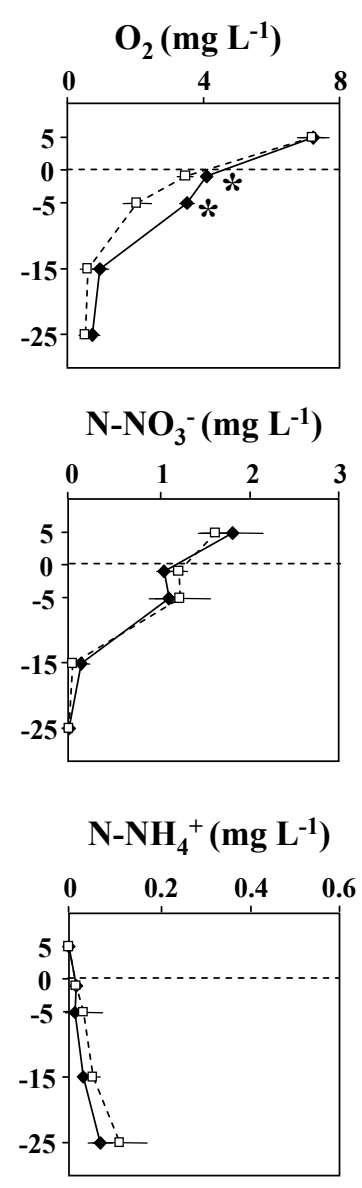

DOC (mg L $\left.{ }^{-1}\right)$

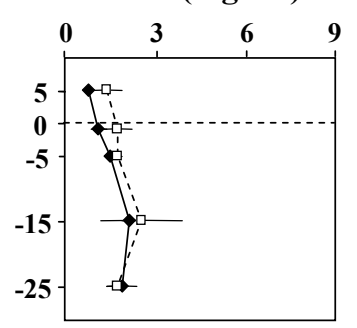

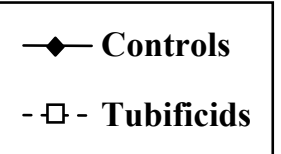

Fig. 2. 
(a) STORM deposit (b) POM-rich deposit (c) POM-low deposit

Number of total bacteria (DAPI) $\mathrm{g}^{-1}$ sed. DW

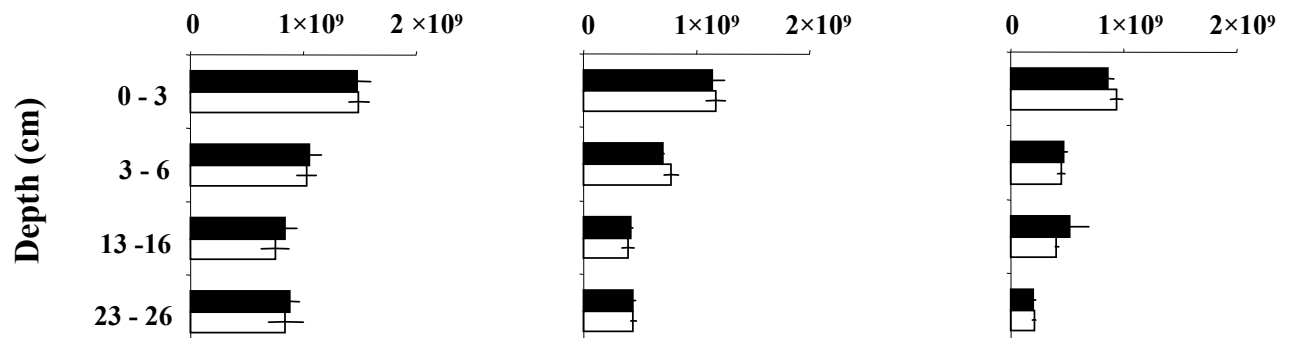

$\%$ of active eubacteria (EUB / DAPI) $\mathrm{g}^{-1}$ sed. DW

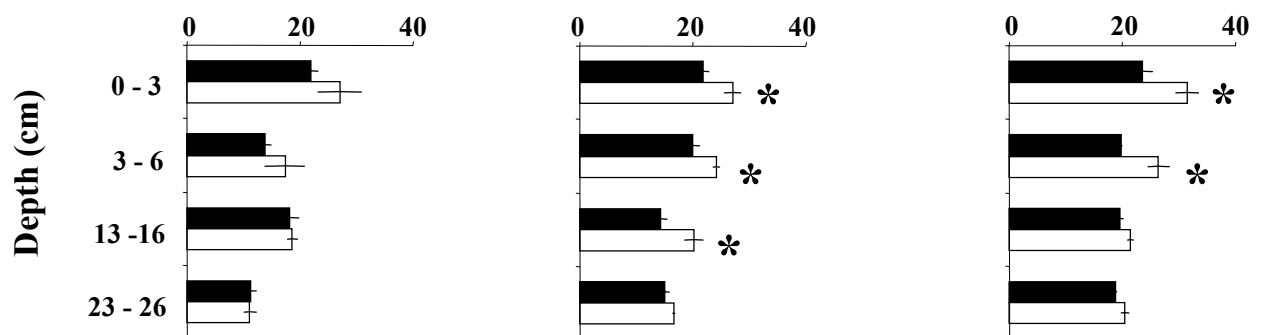

Activity measured with Biolog (global AWCD)

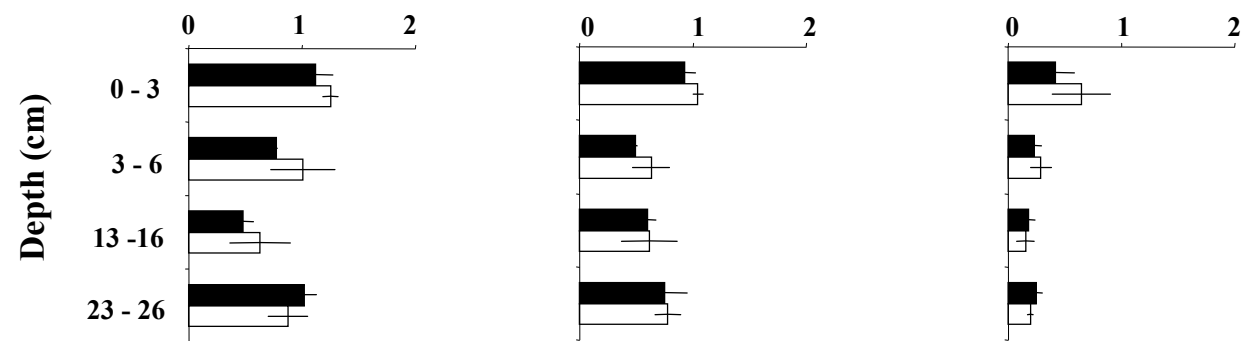

Functional diversity measured with Biolog (number of substrate)
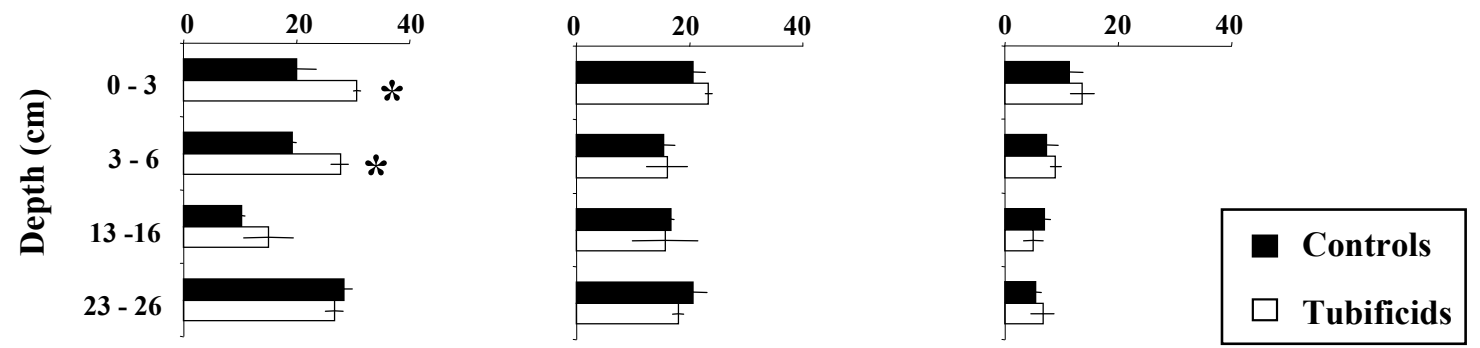

Fig. 3. 
(a) STORM deposit (b) POM-rich deposit (c) POM-low deposit Respiration ( $\mu \mathrm{g} \mathrm{C} \mathrm{h} \mathrm{h}^{-1} \mathrm{~g}^{-1}$ sed. DW)
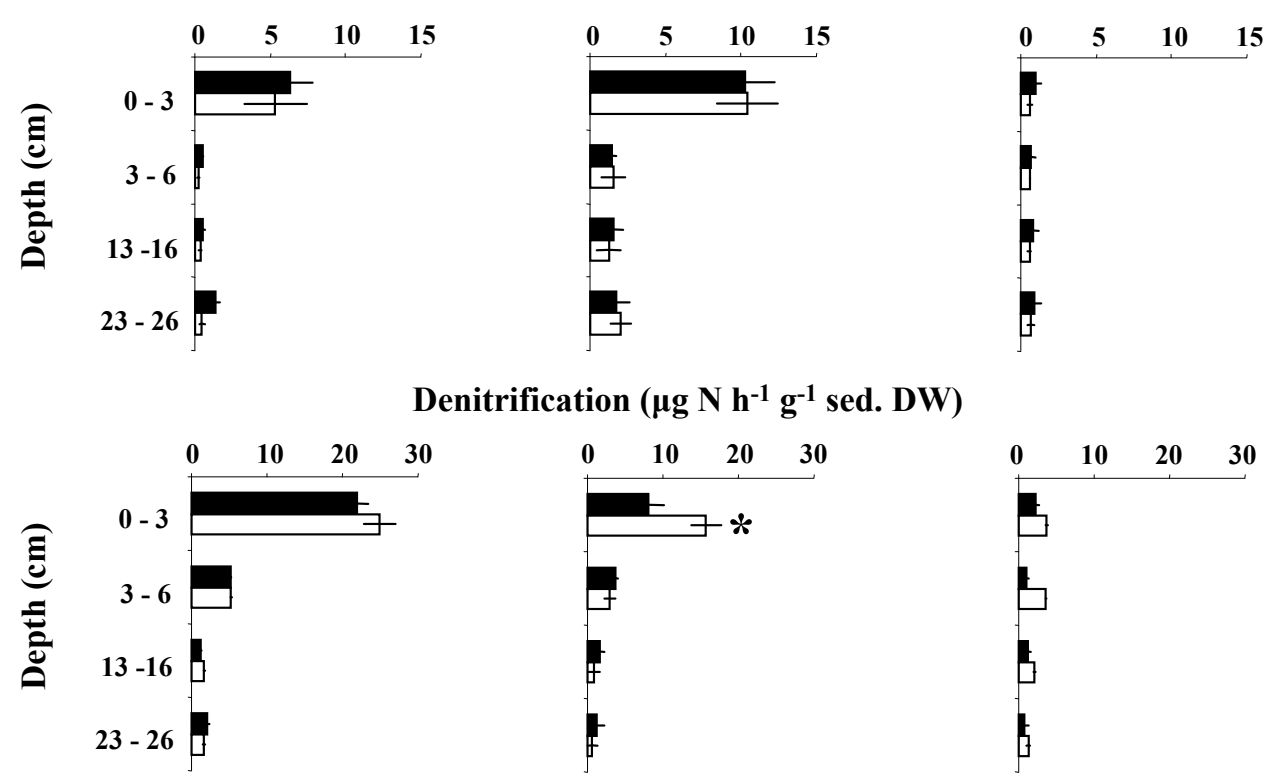

Hydrolytic activity ( $\mu \mathrm{mol}$ FDA $h^{-1} \mathrm{~g}^{-1}$ sed. DW)
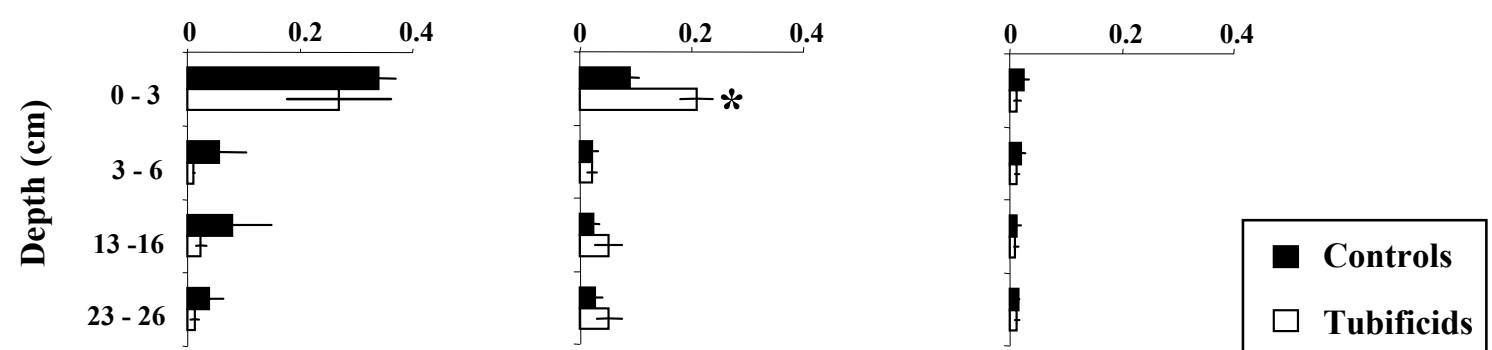

Fig. 4. 
Table 1

Chemical composition of the fresh sediment deposits before their deposition in the columns (mean $\pm \mathrm{SD}, \mathbf{n}=3$ ). Modified from Nogaro et al. (in press)

\begin{tabular}{|c|c|c|c|}
\hline Chemical composition & STORM deposit & POM-rich deposit & POM-low deposit \\
\hline \multicolumn{4}{|l|}{ Nutrients (g kg-1 sed. DW) } \\
\hline Particulate Organic Matter & $70.0 \pm 5.3$ & $85.0 \pm 2.6$ & $20.3 \pm 5.1$ \\
\hline Particulate Organic Carbon & $55.6 \pm 1.6$ & $37.8 \pm 6.1$ & $14.9 \pm 6.1$ \\
\hline Particulate Nitrogen & $2.93 \pm 0.47$ & $1.10 \pm 0.17$ & $0.70 \pm 0.20$ \\
\hline Particulate Phosphorus & $1.11 \pm 0.15$ & $0.41 \pm 0.01$ & $0.35 \pm 0.02$ \\
\hline Atomic $\mathrm{C} / \mathrm{N}$ & $22.4 \pm 3.35$ & $40.1 \pm 7.55$ & $24.9 \pm 6.04$ \\
\hline Atomic $\mathrm{C} / \mathrm{P}$ & $126.3 \pm 14.8$ & $230.5 \pm 34.3$ & $114.0 \pm 37.5$ \\
\hline \multicolumn{4}{|c|}{ Heavy metals (mg kg-1 sed. DW) } \\
\hline Cadmium & $2.8 \pm 0.3$ & $<0.2$ & $<0.2$ \\
\hline Copper & $113.3 \pm 14.2$ & $<10$ & $<10$ \\
\hline Lead & $265.3 \pm 9.2$ & $<10$ & $<10$ \\
\hline Zinc & $77.0 \pm 2.6$ & $<30$ & $<30$ \\
\hline \multicolumn{4}{|c|}{$\begin{array}{l}\text { Polycyclic Aromatic Hydrocarbons } \\
\left(\mathrm{mg} \mathrm{kg}^{-1} \text { sed. DW) }\right.\end{array}$} \\
\hline Acenaphtene & $0.26 \pm 0.07$ & $<0.13$ & $<0.13$ \\
\hline Anthracene & $0.31 \pm 0.09$ & $<0.13$ & $<0.13$ \\
\hline Benzo (a) anthracene & $1.09 \pm 0.23$ & $<0.13$ & $<0.13$ \\
\hline Benzo (a) pyrene & $0.97 \pm 0.19$ & $<0.13$ & $<0.13$ \\
\hline Benzo (b) fluoranthene & $0.82 \pm 0.14$ & $<0.13$ & $<0.13$ \\
\hline Benzo $(\mathrm{k})$ fluoranthene & $0.44 \pm 0.09$ & $<0.13$ & $<0.13$ \\
\hline Benzo (ghi) perylene & $0.84 \pm 0.12$ & $<0.13$ & $<0.13$ \\
\hline Chrysene & $1.22 \pm 0.26$ & $<0.13$ & $<0.13$ \\
\hline Dibenzo $(a, b)$ anthracene & $0.18 \pm 0.03$ & $<0.13$ & $<0.13$ \\
\hline Fluoranthene & $2.54 \pm 0.59$ & $<0.13$ & $<0.13$ \\
\hline Fluorene & $0.29 \pm 0.06$ & $<0.13$ & $<0.13$ \\
\hline Indeno $(1,2,3 \mathrm{~cd})$ pyrene & $0.47 \pm 0.08$ & $<0.13$ & $<0.13$ \\
\hline Naphtalene & $0.14 \pm 0.03$ & $<0.13$ & $<0.13$ \\
\hline Phenanthrene & $1.78 \pm 0.47$ & $<0.13$ & $<0.13$ \\
\hline Pyrene & $1.82 \pm 0.39$ & $<0.13$ & $<0.13$ \\
\hline 2-méthyl naphtalene & $<0.13$ & $<0.13$ & $<0.13$ \\
\hline 2-méthyl fluoranthene & $<0.13$ & $<0.13$ & $<0.13$ \\
\hline
\end{tabular}


Table 2

Average release rates of solutes $\left(\mathrm{N}_{-} \mathrm{NH}_{4}^{+}\right.$and DOC) in the control and the tubificid columns for the three deposit treatments from days 1 to $20($ mean $\pm S D, n=3)$

\begin{tabular}{|c|c|c|c|c|c|c|}
\hline \multirow{2}{*}{$\begin{array}{l}\text { Release rates of } \\
\text { solutes }\left(\mathrm{mg} \mathrm{d}^{-1}\right)\end{array}$} & \multicolumn{2}{|c|}{ STORM deposit } & \multicolumn{2}{|c|}{ POM-rich deposit } & \multicolumn{2}{|c|}{ POM-low deposit } \\
\hline & Controls & Tubificids & Controls & Tubificids & Controls & Tubificids \\
\hline $\mathrm{N}-\mathrm{NH}_{4}^{+}$ & $0.42 \pm 0.05$ & $0.52 \pm 0.03$ & $0.49 \pm 0.01$ & $0.69 \pm 0.08$ & $0.11 \pm 0.02$ & $0.17 \pm 0.05$ \\
\hline DOC & $13.0 \pm 1.55$ & $12.9 \pm 1.66$ & $16.0 \pm 2.18$ & $21.2 \pm 1.04$ & $3.0 \pm 0.14$ & $3.5 \pm 0.31$ \\
\hline
\end{tabular}

Abbreviation: $\mathrm{DOC}=$ Dissolved Organic Carbon. 
Table 3

Mean release from the STORM deposit to water of heavy metals and polycyclic aromatic hydrocarbons in the control and the tubificid columns at days 1,8 and $15($ mean $\pm S D, n=3)$

\begin{tabular}{|c|c|c|c|c|c|c|}
\hline \multirow{2}{*}{$\begin{array}{l}\text { Pollutant release from } \\
\text { STORM deposit to water }\end{array}$} & \multicolumn{2}{|c|}{ DAY 1} & \multicolumn{2}{|c|}{ DAY 8} & \multicolumn{2}{|c|}{ DAY 15} \\
\hline & Controls & Tubificids & Controls & Tubificids & Controls & Tubificids \\
\hline \multicolumn{7}{|l|}{ Heavy metals $\left(\mu \mathrm{g} \mathrm{L}^{-1}\right)$} \\
\hline Cadmium & $<4.6$ & $<4.6$ & $<4.6$ & $<4.6$ & $<4.6$ & $<4.6$ \\
\hline Copper & $<1.1$ & $<1.1$ & $<1.1$ & $<1.1$ & $<1.1$ & $<1.1$ \\
\hline Lead & $17.3 \pm 1.5$ & $13.3 \pm 3.1$ & $18.0 \pm 4.4$ & $21.7 \pm 2.5$ & $15.0 \pm 4.4$ & $13.3 \pm 4.2$ \\
\hline Zinc & $<0.3$ & $<0.3$ & $<0.3$ & $<0.3$ & $\begin{array}{l}1 J .0+4.4 \\
<0.3\end{array}$ & $<0.3$ \\
\hline \multicolumn{7}{|l|}{ PAHs (ng L $\left.L^{-1}\right)$} \\
\hline Acenaphtene & $14.3 \pm 2.1$ & $15.0 \pm 13.2$ & $17.0 \pm 2.0$ & $19.3 \pm 3.5$ & $16.3 \pm 2.1$ & $16.0 \pm 1.0$ \\
\hline Anthracene & $<10$ & $<10$ & $<10$ & $<10$ & $<10$ & $<10$ \\
\hline Benzo (a) anthracene & $<10$ & $<10$ & $<10$ & $<10$ & $<10$ & $<10$ \\
\hline Benzo (a) pyrene & $<10$ & $<10$ & $<10$ & $<10$ & $<10$ & $<10$ \\
\hline Benzo (b) fluoranthene & $<10$ & $<10$ & $<10$ & $<10$ & $<10$ & $<10$ \\
\hline Benzo (k) fluoranthene & $<10$ & $<10$ & $<10$ & $<10$ & $<10$ & $<10$ \\
\hline Benzo (ghi) perylene & $<10$ & $<10$ & $<10$ & $<10$ & $<10$ & $<10$ \\
\hline Chrysene & $<10$ & $<10$ & $<10$ & $<10$ & $<10$ & $<10$ \\
\hline Dibenzo $(a, b)$ anthracene & $<10$ & $<10$ & $<10$ & $<10$ & $<10$ & $<10$ \\
\hline Fluoranthene & $<10$ & $<10$ & $<10$ & $<10$ & $<10$ & $<10$ \\
\hline Fluorene & $<10$ & $<10$ & $<10$ & $<10$ & $<10$ & $<10$ \\
\hline Indeno $(1,2,3 \mathrm{~cd})$ pyrene & $<10$ & $<10$ & $<10$ & $<10$ & $<10$ & $<10$ \\
\hline Naphtalene & $59.0 \pm 30.1$ & $87.3 \pm 78.2$ & $60.7 \pm 9.0$ & $64.0 \pm 9.6$ & $65.7 \pm 5.8$ & $57.3 \pm 9.0$ \\
\hline Phenanthrene & $11 \pm 1.7$ & $14.7 \pm 1.2$ & $<10$ & $<10$ & $<10$ & $<10$ \\
\hline Pyrene & $<10$ & $<10$ & $<10$ & $<10$ & $<10$ & $<10$ \\
\hline 2-méthyl naphtalene & $<10$ & $<10$ & $<10$ & $<10$ & $<10$ & $<10$ \\
\hline 2-méthyl fluoranthene & $<10$ & $<10$ & $<10$ & $<10$ & $<10$ & $<10$ \\
\hline
\end{tabular}

Abbreviation: PAHs = Polycyclic Aromatic Hydrocarbons. 